Syntax Literate : Jurnal Ilmiah Indonesia p-ISSN: 2541-0849

e-ISSN : 2548-1398

Vol. 5, No. 3 Maret 2020

\title{
HUBUNGAN PENGETAHUAN KESEHATAN REPRODUKSI REMAJA PUTRI TERHADAP KEJADIAN MENGHADAPI PREMENSTRUAL SYNDROME
}

\author{
Heny Puspasari \\ Sekolah Tinggi Ilmu Kesehatan (STIKes) Cirebon \\ Email: kikipramana211@yahoo.co.id
}

\begin{abstract}
Adolescent reproductive health is a matter that must be considered by each individual specifically the teenager himself. Because with attention will appear affection will appear in the future and its generation. Thus there must be knowledgeable about the health of adolescent regeneration to be avoided. Premenstrual syndrome, a disease caused by routine and related to the menstrual cycle, usually appears 7-10 days before menstruation and the elimination of compilation begins. This research uses analytic observational research design with cross-sectional is a study that discusses risk factors and influences, by utilizing, observing or collecting data at any time (time approach). Premenstrual syndrome was as many as $12(85.7 \%)$ respondents who did not know the knowledge of PMS. Because teenage lack of knowledge about health education needs to be improved from health workers. While respondents who know the knowledge of PMS and do not have 14 (87.5\%). They get health knowledge from schools and the internet as well as updating from health workers.
\end{abstract}

Keywords: Reproduction, Observational, Premenstrual Syndrome

\section{Abstrak}

Kesehatan reproduksi pada remaja adalah suatu hal sangat harus diperhatikan oleh setiap individu khususnya remaja itu sendiri. Karena dengan perhatian akan muncul rasa sayang akan masa depan dirinya dan generasinya. Dengan demikian harus adanya pengetahuan akan kesehatan reroduksi remaja guna menghindari. Premenstrual syndrome yaitu suatu kondisi berupa gejala terjadi secara rutin dan berhubungan dengan siklus menstruasi, gejala biasanya muncul 7-10 hari sebelum menstruasi dan menghilang ketika menstruasi dimulai. Penelitian ini menggunakan desain penelitian observasional analitik dengan cross sectional adalah suatu penelitian yang mempelajari dinamika korelasi antara faktor-faktor risiko dan efek, dengan cara pendekatan, observasional atau pengumpulan data sekaligus pada saat (point time approach). Adapun hasil yang diperoleh hubungan pengetahuan kesehatan reproduksi remaja putri terhadap kejadian menghadapi premenstrual syndrome adalah sebanyak $12(85,7 \%)$ responden yang cemas karena tidak mengetahui pengetahuan PMS. Karena kurang tahunya remaja tentang pendidikan kesehatan reproduksi dan kurangnya penyuluhan dari tenaga kesehatan. Sedangkan responden yang mengetahui pengetahuan PMS dan tidak cemas terdapat 14 $(87,5 \%)$. Mereka mendapatkan pengetahuan kesehatan reproduksi dari sekolah dan internet serta penyuluhan dari tenaga kesehatan. 
Heny Puspasari

Kata kunci : Reproduksi, Observasional, Premenstrual Syndrome

\section{Pendahuluan}

Kesehatan reproduksi ialah satu keadaan sejahtera fisik, mental serta social secara utuh, tidak semata-mata bebas dari penyakit atau kecacatan dalam semua hal yang berhubungan dengan system reproduksi, serta fungsi dan prosesnya (Mubarak Ali, 2010).

Usia remaja merupakan usia beresiko (Rohaeni, 2017). Masa remaja adalah masa peralihan antara masa kanak-kanak dan masa dewasa, yang dimulai pada saat terjadinya pematangan seksual yaitu antar ausia 11 atau 12 tahun sampai dengan 20 tahun yaitu menjelang masa dewasa muda (Mohammad Ali, 2009)

Masa remaja dibagi menjadi 3 tahap yaitu remaja awal ,remaja tengah dan remaja akhir.Remaja putri yang sudah memasuki masa pubertas yaitu ditandai dengan berfungsinya ovarium dan mengalami menstruasi pertama (menarche).

Menstruasi adalah pelepasan dinding rahim (endrometrium) yang disertai perdarahan dan terjadi setiap bulannya kecualipadasaat kehamilan. Menstruasi yang terjadi terus menerus disetiap bulannya disebut dengan siklus menstruasi.Menstruasi biasanya terjadi pada usia 11 tahun dan berlangsung hingga menopause. Normalnya, menstruasi berlangsung selama 3-7 hari (Arikunto, 2010).

Sebelum mengalami menstruasi remaja putrid akan mengalami Premenstrual syndrome. Premenstrual syndrome (PMS) adalah suatu keadaan dimana sejumlah gejala terjadi secara terus menerus serta berkaitan dengan siklus menstruasi, gejala biasanya timbul 7-10 hari sebelum menstruasi serta menghilang ketika menstruasi berlangsung. Gejala yang dapat ditemukan pada premenstrual syndrome adalah perubahan fisik, perubahan suasana hati, dan perubahan mental (Nugroho\&Utama, 2014). Gejala yang timbul pada setiap individu berbeda namun gejala yang sering terjadi adalah kelelahan, sifat lekas marah, bengkak abdominal, dada sakit, suasana hati labil antara kesedihan dan kemarahan yang silih berganti serta depresi.

Akibat adanya sindrom ini masih abstrak. Beberapa teori menyebutkan antara lain karenafaktor hormonal yakni ketidak selarasan antara hormon estrogen serta progesteron. hal ini karena hormone esterogen yang berlebihan. para peneliti menyampaikan, kemungkinan yang akan terjadi ialah terdapat kejanggalan genetic pada sensitivitas reseptor serta system pembawa pesan yang melaporkan pengeluaran hormone seks kedalam sel. Antara lain, hal itu berkaitan dengan gangguan perasaan, factor kejiwaan, masalah sosial, serta fungsi serotonin yang penderita alami.

Berdasarkan laporan WHO (World Health Organization) 65,7\% remaja putrid mengalami Premenstrual syndrome, Penelitian Delara (2013) tentang Premenstrual syndrome, menunjukkan bahwa di Indonesia 66,3\% remaja dengan PMS ringan, 31,4\% dengan PMS sedang, dan 2,3\% dengan PMS berat. Data dari PKPR Bandung menunjukan bahwa remaja putri yang mengalami Premenstrual syndrome 54,9\%. (Suharsimi, 2005) 
Pengetahuan remaja tentang Premenstrual syndrome serta antisipasi pencegahan adalah stimulus yang diinginkan bisa membentuk pola perilaku remaja yang baik. Dengan mengenali gejala gejala tentang syndrome haid diinginkan remaja berupaya guna mengatasinya dengan benar bukan dengan membiarkannya.

Kurangnya pengetahuan, pengalaman, dan juga kurangnya informasi yang dimiliki oleh wanita terutama oleh remaja putri tentang premenstrual syndrome dapat memperberat gejala-gejala yang timbul. Terkadang remaja putrid mencoba mengatasi premenstrual syndrome dan bersifat coba-coba tanpa adanya pengetahuan yang cukup dan benar (Suastina, Ticoalu, \& Onibala, 2013).

Upaya pemerintah untuk mengurangi terjadinya premenstrual syndrome dengan cara memberikan penyuluhan dan bekerja sama dengan puskesmas dengan memberikan pendidikan kesehatan reproduksi pada remaja putri (Dorland, 2019).

Berdasarkan penilitian sebelumnya di SMK RISE KEDAWUNG Kabupaten Cirebon bahwa dari 10 remaja putri 6 diantaranya mengaku mengalami Premenstrual syndrome.

Remaja yang mengaku mengalami menstruasi adalah remaja putrid tengah dan remaja akhir yang sudah mengalami menstruasi sebelumnya sehingga mereka sudah mengetahui tentang premenstrual syndrome yang mereka alami.

Gejala-gejala premenstrual syndrome terdiri atas gangguan emosional berupa iritabilitas, Pada wanita dikatakan PMS jika ditemukan 8 gejala yang sering muncul atau terjadi (Maulana, 2008).Gejala psikologis yang paling umum adalah lekas marah, perasaan labil, dan mudah menangis, sedangkan gejala fisik yang paling umum adalah kelelahan, nyeri payudara, jerawat, dan perubahan nafsu makan dengan mengidam makanan.

Beberapa faktor yang menyebakan terjadinya premenstrual syndrome antara lain :Stres, status gizi, kebiasaan makan makanan tertentu, aktifitas olahraga, merokok dan alcohol. Berdasarkan latar belakang tersebut penulis tertarik untuk meneliti lebih lanjut mengenai Hubungan Pengetahuan Kesehatan Reproduksi Remaja Putri Terhadap Kejadian Menghadapi Premenstrual Syndrome di SMK RISE KEDAWUNG Tahun 2018 (Bungasari, Tendean, \& Suparman, 2015)

Hasil studi pendahuluan oleh Riski Nurul Prajati pada tahun 2014 bahwa remaja yang kurang memiliki pengetahuan tentang kesehatan reproduksi sebanyak 73,3\%, dan tingkat kecemasan yang mereka hadapi sebanyak 65\%. Dan dikatakan yakni ada hubungan pengetahuan kesehatan reproduksi remaja putri terhadap kejadian menghadapi Premenstrual Syndrome, dibuktikan dengan nilai signifikan sebesar 0.003 $(\mathrm{p}<5 \%)$.

Berdasarkan latar belakang, maka yang menjadi rumusan masalah dalam penelitian iniadalah "Adakah Hubungan Pengetahuan Kesehatan Reproduksi Remaja Putri Terhadap Kejadian Menghadapi Premenstrual Syndrome di SMK RISE KEDAWUNG Tahun 2018. 
Heny Puspasari

\section{Metode Penelitian}

Penelitian ini menggunakan desain penelitian observasional analitik dengan pendekatan cross sectional ialah suatu penelitian guna mempelajari dinamika korelasi antara faktor-faktor risiko dengan efek, dengan metode pendekatan, observasional dan pengumpulan data sekaligus pada suatu saat (point time approach). (Notoatmodjo, 2010).

Variabel penelitian merupakan sesuatu yang berupa apa saja yang ditetapkan oleh peneliti untuk digeluti sehingga memperoeh informasi tentang hal tersebut, kemudian di tarik, kesimpulannya.

Dalam penelitian ini terdapat dua variable yaitu variable bebas dan variable terikat.Variabel bebas pada penelitian ini ialah pengetahuan premenstrual syndrome dan variable terikatnya adalah kecemasan remaja putri saat mengalami premenstrual syndrome di SMK Rise Kedawung.

Alat pengumpulan data yang dipergunakan untuk mengukur tingkat pengetahuan remaja putri tentang premenstrual syndrome adalah data primer yang berupa kuesioner yang diberikan kepada siswi. Kuesioner adalah daftar pernyataan-pertanyaan yang sudah tersusun dengan baik, matang, dimana responden telah memberikan jawaban atau dengan memberikan kode-kode tertentu.

\section{Hasil dan Pembahasan}

Tabel Distribusi Responden Hubungan Pengetahuan Kesehatan Reproduksi Remaja Putri Terhadap Kejadian Menghadapi Premenstruan Syndrome

Tabel 1 Distribusi Responden

\begin{tabular}{|c|c|c|c|c|c|c|c|}
\hline \multirow{3}{*}{$\begin{array}{l}\text { Pengetahuan } \\
\text { PMS }\end{array}$} & \multicolumn{4}{|c|}{ Kecemasan Pada Saat PMS } & \multirow{2}{*}{\multicolumn{2}{|c|}{ Jumlah }} & \multirow{3}{*}{ Pvalue } \\
\hline & \multicolumn{2}{|c|}{ Cemas } & \multicolumn{2}{|c|}{ Tidak Cemas } & & & \\
\hline & $\mathrm{N}$ & $\%$ & $\mathrm{~N}$ & $\%$ & $\mathrm{~N}$ & $\%$ & \\
\hline $\begin{array}{l}\text { Tidak } \\
\text { Mengetahui }\end{array}$ & 12 & $85,7 \%$ & 2 & $14,3 \%$ & 14 & $100 \%$ & \multirow{3}{*}{0,001} \\
\hline Mengetahui & 2 & $12,5 \%$ & 14 & $87,5 \%$ & 16 & $100 \%$ & \\
\hline Jumlah & 14 & $46,7 \%$ & 16 & $53,3 \%$ & 30 & $100 \%$ & \\
\hline
\end{tabular}

Hasil Analisis Hubungan Pengetahuan PMS (Premenstrual Syndrome) Dalam Mengatasi Kecemasan Saat PMS diperoleh bahwa ada sebanyak $12(85,7 \%)$ responden yang cemas karena tidak mengetahui pengetahuan PMS. Sedangkan responden yang mengetahui pengetahuan PMS dan tidak cemas terdapat 14 (87,5\%). Hasil uji chisquare diperoleh nilai pvalue $=0,001(<0,05)$ maka dapat disimpulkan bahwa ada Hubungan Pengetahuan PMS (Premenstrual Syndrome) Dalam Mengatasi Kecemasan Saat PMS di SMK RISE Kedawung.

Berdasarkan hasil penelitian yang telah dilakukan, maka peneliti akan membahas sebagai berikut:

Berdasarkan Tabel 1 menunjukan hubungan pengetahuan kesehatan reproduksi remaja putri terhadap kejadian premenstrual syndrome di SMK Rise Kedawung adalah 
sebanyak $12(85,7 \%)$ responden yang cemas karena tidak mengetahui pengetahuan PMS. Karena kurang tahunya remaja tentang pendidikan kesehatan reproduksi dan kurangnya penyuluhan dari tenaga kesehatan.Sedangkan responden yang mengetahui pengetahuan PMS dan tidak cemas terdapat 14 (87,5\%). Mereka mendapatkan pengetahuan kesehatan reproduksi dari sekolah dan internet serta penyuluhan dari tenaga kesehatan.

Premenstrual syndrome merupakan sekelompok gejala yang terjadi dalam fase luteal dari siklus haid. Nama lain PMS ialah PreMenstrual Tension yang merupakan kumpulan gejala fisik, psikologis, serta emosi yang berhubungan dengan siklus menstruasi perempuan. Sindrom premenstruasi ialah kumpulan gejala yang muncu saat menjelang haid yang mengakibatkan gangguan pada pekerjaan serta gaya hidup seseorang.

Sementara itu gejala-gejala berupa mudah tersinggung, mudah marah, depresi, sensitif, cengeng, cemas, susah konsentrasi, bingung, sulit istirahat, serta merasa kesepian masuk ke dalam psychologic symptoms. Secara fisik timbul juga gejala sakit kepala, payudara bengkak serta terasa keras, nyeri punggung, nyeri perut dan rasa penuh, bengkak pada kaki serta tangan, mual, nyeri otot serta persendian. Dickerson menyampaikan sebagai physical symptoms. Sekitar 80 hingga $95 \%$ perempuan antara 16-45 tahun mengalami gejala-gejala premenstruasi yang bisa mengganggu.

\section{Kesimpulan}

Berdasarkan hasil penelitian dan pembahasan yang telah diuraikan, tentang "Hubungan Pengetahuan Kesehatan Reproduksi Remaja Putri Terhadap Kejadian Menghadapi Premenstrual Syndrome". Maka dapat disimpulkan bahwa hubungan pengetahuan kesehatan reproduksi remaja putri terhadap kejadian menghadapi premenstrual syndromeadalahsebanyak12 $(85,7 \%)$ responden yang cemas karena tidak mengetahui pengetahuan PMS. Karena kurang tahunya remaja tentang pendidikan kesehatan reproduksi dan kurangnya penyuluhan dari tenaga kesehatan. Sedangkan responden yang mengetahui pengetahuan PMS dan tidak cemas terdapat 14 (87,5\%). Mereka mendapatkan pengetahuan kesehatan reproduksi dari sekolah dan internet serta penyuluhan dari tenaga kesehatan.

Diharapkan dapat mengembangkan penelitian yang lebih lanjut mengenai hubungan pengetahuan kesehatan reproduksi remaja putri terhadap kejadian menghadapi premesntrual syndrome dan hasil penelitian ini dapat digunakan sebagai sumber bacaan untuk penelitian selanjutnya. 
Heny Puspasari

\section{BIBLIOGRAFI}

Ali, Mohammad. (2009). Psikologi Remaja. Jakarta: Bumi Aksara.

Ali, Mubarak. (2010). Psikologi Remaja Perkembangan Peserta Didik. Jakarta: BumiAksara.

Arikunto, Suharsimi. (2010). Prosedur penelitian. Jakarta: rineka cipta.

Bungasari, Septa Ayu, Tendean, Hermie M. M., \& Suparman, Eddy. (2015). Gambaran sindroma prahaid pada remaja. E-CliniC, 3(1).

Dorland, W. A. Newman. (2019). Kamus kedokteran dorland. EGC.

Maulana, Mirza. (2008). Penyakit kehamilan dan pengobatannya. Yogyakarta: Kata Hati.

Notoatmodjo, Soekidjo. (2010). Metodologi penelitian kesehatan. Jakarta: rineka cipta.

Rohaeni, Ela. (2017). Pengaruh Program Pusat Informasi dan Konseling Kesehatan reproduksi remaja (PIK-KRR) terhadap pengetahuan kesehatan reproduksi remaja pada siswa kelas VIII di SMPN 1 baleendah. Syntax Literate; Jurnal Ilmiah Indonesia, 2(7), 40-52.

Suastina, I. Dewa Ayu Rai, Ticoalu, Hanny, \& Onibala, Franly. (2013). Pengaruh pendidikan kesehatan terhadap tingkat pengetahuan siswi tentang SADARI sebagai deteksi dini kanker payudara di SMA Negeri 1 Manado. Jurnal Keperawatan, 1(1).

Suharsimi, Arikunto. (2005). Manajemen penelitian. Jakarta: Rineka Cipta. 